\title{
Genetic variation and prevalence of blood parasites do not correlate among bird species
}

\author{
Robert Poulin*, Leigh J. Marshall and Hamish G. Spencer \\ Department of Zoology, University of Otago, P.O. Box 56, Dunedin, New Zealand \\ (Accepted 3 November 1999)
}

\begin{abstract}
Models of host-parasite co-evolution suggest that parasites can exert frequency-dependent selection on their hosts, favouring rare alleles that confer resistance against widespread parasites and thus contributing to the maintenance of genetic variation, at some loci at least. If parasites are important in maintaining variation at many loci, then host species incurring a high prevalence of parasite infections should exhibit greater levels of genetic variation than host species incurring a lower prevalence. Using data from electrophoretic studies and from field surveys of haematozoan infections, we constructed a dataset including 103 species of North American and European birds to test this prediction. After controlling for sampling effort and phylogenetic influences, we found no relationship between parasite prevalence and either heterozygosity or polymorphism. These results do not support a role for parasites in the overall maintenance of genetic variation via frequency-dependent selection.
\end{abstract}

Key words: comparative analysis, frequency-dependent selection, genetic variation, haematozoa, heterozygosity

\section{INTRODUCTION}

The ubiquity of genetic variability in natural populations of plants and animals (reviewed in Nevo, 1978; Nei \& Graur, 1984; Evans, 1987) has been described by Lewontin (1974) as 'the paradox of variation'. To date, we have no good theoretical explanation for how this variation is maintained (Lewontin, 1974; Kimura, 1983; Nei, 1987; Maynard Smith, 1989; Spencer \& Marks, 1993; Kreitman \& Akashi, 1995). Neither the (strictly) neutral theory nor balancing selection adequately account for the patterns of genetic variation observed, either at the allozyme or DNA level (Kreitman \& Akashi, 1995). One possibility is that frequency-dependent selection favouring rare alleles and selecting against common ones actively preserves genetic variation (Clarke \& Partridge, 1988). This type of selection pressure could be exerted by parasites, since rare genotypes of the host are likely to confer greater resistance against widespread parasites (Hamilton, 1982). Hence, the ubiquity of parasites should provide an omnipresent force favouring the maintenance of genetic variation. The co-evolutionary arms race between a host and a parasite results in any genetically-determined mechanism of resistance rapidly

*All correspondence to: Robert Poulin.

E-mail: robert.poulin@stonebow.otago.ac.nz becoming obsolete and inefficient, which in turns leads to pressure on hosts to continually change gene combinations. Indeed, sexual reproduction itself is viewed as an adaptation against parasites by allowing gene recombination and promoting genetic variation (Hamilton, 1980; Lively, 1987; Hamilton, Axelrod \& Tanese, 1990; but see Dybdahl \& Lively, 1995; Ronsheim, 1996).

Although frequency-dependent selection should maintain high levels of genetic variation indefinitely, firm empirical evidence for this phenomenon is scanty (Chaboudez \& Burdon, 1995; Clay \& Kover, 1996; Apanius et al., 1997). It seems that parasitic protozoans and other micro-organisms can maintain polymorphism at particular loci in humans (see review in Hamilton et al., 1990), and that parasitic nematodes maintain variation at the major histocompatibility complex in sheep (Paterson, Wilson \& Pemberton, 1998). But our question is whether parasites maintain overall genetic variation. Within species, heterozygous fish harbour fewer parasites than homozygous conspecifics (Lively, Craddock \& Vrijenhoek, 1990), and bumblebee colonies that are genetically heterogeneous experience lower levels of parasitism than homogeneous colonies (Liersch \& Schmid-Hempel, 1998). Thus, parasites appear to respond to overall levels of genetic variation and exert strong selective pressures on their hosts. We set out to test one further prediction of this hypothesis. 
If parasites are important in maintaining overall levels of genetic variation (rather than just variation at specific loci known to be involved in parasite resistance), a simple and testable prediction is that host species exhibiting higher levels of genetic variation do so in response to higher prevalences of parasite infections. In other words, the greater the parasite-mediated selection pressure, the greater the resultant level of genetic variation. Thus, whereas genetically more variable individuals should incur lower levels of parasitism, genetically variable species should incur higher levels. These opposite expected correlations parallel the withinspecies and among-species predictions of Hamilton \& Zuk's (1982) hypothesis of parasite-mediated sexual selection. They argued that although heavily parasitized individuals should display a duller sexual coloration than their uninfected conspecifics, species incurring high levels of parasitism are under more intense selection pressure to evolve and maintain bright colours as sexual signals of mate quality than species incurring lower levels of parasitism.

Here we test this prediction using data gathered from protein electrophoretic studies on birds and from field surveys of prevalence of avian blood parasites. The pathogenic effects of protozoans parasitic in avian blood, or haematozoans, have been well documented (reviewed in Atkinson \& van Riper, 1991; John, 1997). Across bird species, haematozoan prevalence even correlates positively with annual mortality rates (Sorci \& Møller, 1997). The selective pressure that haematozoans exert on bird hosts is illustrated by their influence on the evolution of sexually selected characters, mating systems and life-history traits (Hamilton \& Zuk, 1982; Read, 1991; Ricklefs, 1992; John, 1995). These influences, combined with the short generation times of protozoans relative to their avian hosts, should make them good agents of frequency-dependent selection promoting high levels of genetic variation.

Our specific objectives were to relate prevalence of haematozoan infections to genetic variation among species of North American and European birds. We investigated whether bird species incurring a higher prevalence of infection by haematozoans (and which are presumably subject to stronger frequency-dependent selection pressures) exhibit greater levels of allozyme variation than related bird species incurring lower prevalence (and subject to weaker pressures). Our analysis controls for sampling effort and phylogenetic influences, two potentially confounding factors. We used two measures of genetic variation, heterozygosity (the average proportion of heterozygous loci per individual) and polymorphism (the proportion of polymorphic loci among the total number of loci surveyed). Note that we specifically did not set out to examine loci known to be involved in resistance to blood parasites; our question is about how we can explain overall levels of genetic variation. Even if the loci commonly tested in electrophoretic studies do not provide a precise measure of genetic variation in the entire gene pool of a species, they are still useful for comparative purposes. For instance, Petrie, Doums \& Møller (1998) recently showed that variation at the same allozyme loci we used correlates with the degree of extra-pair paternity among bird species. The allozymic variation we investigated may only be the tip of the iceberg with respect to overall genetic variation, but it is its best documented component and one used previously in comparative analyses. To our knowledge, our study is the first attempt to link parasitism with genetic variation across a large number of bird species.

\section{METHODS}

Data on heterozygosity, $H$, and polymorphism, $P$, were obtained from published electrophoretic studies, many of which were found through existing literature surveys (Mani, 1983; Barrowclough, Johnson \& Zink 1985; Baker \& Strauch, 1986; Evans, 1987). We used 2 estimates of polymorphism, based on 2 different criteria for polymorphism: $P 99$, for which the frequency of the most common allele had to be $\leq 0.99$, and P95, for which the frequency of the most common allele had to be $\leq 0.95$. Because of the high variance in single-locus polymorphism among loci, estimates of genetic variation are far more severely influenced by the number of loci sampled than by the number of individuals examined (Nei \& Roychoudhury, 1974; Nei, 1978; Gorman \& Renzi, 1979). Thus, following Nei's (1978) suggestions, estimates were only used if at least 20 loci had been investigated from at least 5 individual birds, or if at least 2 individuals had been used and scored at at least 25 loci. When 2 or more studies per bird species were available, we averaged estimates of heterozygosity and polymorphism, weighting by the number of loci, to obtain single values of $H, P 95$ and P99 per species.

Parasite data were obtained from surveys of field studies (Greiner et al., 1975; Peirce, 1981). Prevalence was calculated as the percentage of individuals for which examination of blood smears revealed infections by 1 or more haematozoan taxa. Since estimates of prevalence based on small numbers of sampled individuals are imprecise (Gregory \& Blackburn, 1991), bird species with $<10$ sampled individuals were discarded. Overall prevalence was used since this value tends to correlate well with prevalence of the main haematozoan genera: Leucocytozoon $(r=0.854, n=76, P=0.001)$, Haemoproteus $(r=0.647, n=76, P=0.001)$, Plasmodium $(r=0.104, \quad n=61, \quad P=0.404), \quad$ and Trypanosoma $(r=0.446, n=64, P=0.002)$. In all bird species, both the parasite and the genetic data included in the analysis came from the same geographical region, either eastern North America, western North America, or Europe. Finally, data on body size for each bird species were obtained from Dunning (1993) since this variable may be associated with parasite prevalence and mask any relationship with genetic variation (John, 1995).

We used Felsenstein's (1985) phylogenetically independent contrasts method for the comparative 
analysis. Contrasts were computed on log-transformed data using the CAIC 2.0 statistical package (Purvis \& Rambaut, 1994). The method consists of deriving statistically independent contrasts between sister taxa from a phylogeny, and using these contrasts to test for relationships between variables. We used the avian phylogeny of Sibley \& Ahlquist (1991), supplemented with some additional taxonomic or phylogenetic information (American Ornithologists' Union, 1983; Martin \& Clobert, 1996; Westneat \& Sherman, 1997), to obtain contrasts. Contrasts need to be standardized for the time since divergence of sister taxa, or branch lengths in the phylogeny (Garland, Harvey \& Ives, 1992). We used Sibley \& Ahlquist's (1991) $\Delta T_{50} H$ measures of divergence, based on DNA-DNA hybridization, as estimates of branch lengths to standardize contrasts. Relationships among contrasts were assessed using correlations forced through the origin (Garland et al., 1992). To control for the confounding effect of sampling effort (either number of individuals or number of loci examined), residuals of a regression of the variable of interest on the confounding variable were used instead of uncorrected contrasts (Garland et al., 1992). This approach, using the same parasite data, avian phylogeny and comparative method, has been used previously to investigate the relationship between blood parasites and several ecological characteristics of birds (e.g. Read, 1991; John, 1995; Sorci \& Møller, 1997).

\section{RESULTS}

Overall, the data set included 103 bird species, from 56 genera and 20 families (Table 1). There is much variation among bird families in levels of parasitism and genetic variation, suggesting that these data are subject to some sort of phylogenetic constraints and that using phylogenetically independent contrasts is necessary.

Bird body mass did not correlate with any of the variables investigated and was thus ignored in further analyses. The number of individual birds examined for parasites correlated positively with the number of individuals examined to determine genetic variation ( $r=0.341, n=64$ sets of contrasts, $P<0.01$ ). However, the number of birds examined for parasites did not correlate with haematozoan prevalence $(r=0.124, n=64$ sets of contrasts, $P=0.327$ ), and there was no need to correct prevalence for sampling effort. All three measures of genetic variation correlated positively with one another ( $H$ vs. P99: $r=0.686, n=52$ sets of contrasts, $P<0.001 ; H$ vs. $P 95: r=0.745, n=58, P<0.001 ; P 99$ vs. P95: $r=0.874, n=52, P<0.001$ ), but were still analysed separately. Heterozygosity correlated positively with the number of loci investigated $(r=0.391, n=64$ sets of contrasts, $P<0.01$ ), whereas both measures of polymorphism correlated positively with the number of individual birds examined (P99: $r=0.447, n=52$ sets of contrasts, $P<0.001 ; P 95: \quad r=0.239, n=58, P<0.10)$, suggesting that correcting for sampling effort may be necessary.
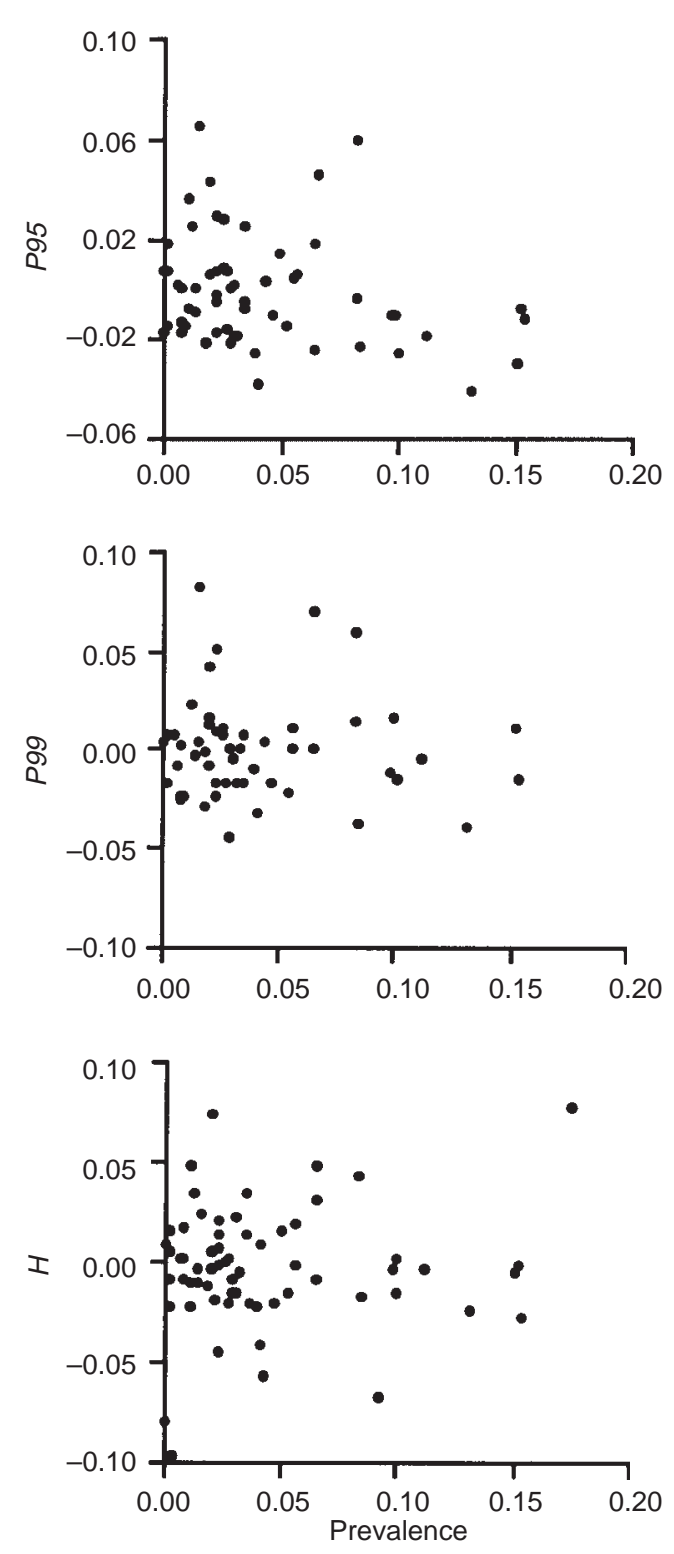

Fig. 1. Relationship between prevalence of avian blood parasites and three measures of genetic variation in birds, computed using phylogenetically independent contrasts standardized for branch lengths. Heterozygosity $(H)$ is corrected for the number of loci investigated, whereas $P 99$ and $P 95$ are corrected for the number of individuals examined. Correlations are forced through the origin; all are statistically non-significant $(H: r=-0.055, n=64$ sets of contrasts, $P=0.688 ; P 99: r=-0.045, n=52, P=0.765 ; P 95: r=-0.206$, $n=58, P=0.118)$.

Haematozoan prevalence did not correlate significantly with either of the three measures of genetic variation (even when each parasite genus was analysed separately), independently of whether or not these measures were corrected for sampling effort using residuals (Fig. 1). In other words, avian taxa incurring higher prevalence of haematozoans than their sister taxa do not also display consistently higher levels of genetic variation. 
Table 1. Haematozoan prevalence data and genetic variation data for the 103 bird species included in the analysis

\begin{tabular}{|c|c|c|c|c|c|c|}
\hline $\begin{array}{l}\text { Family } \\
\text { species }\end{array}$ & $\begin{array}{l}\text { Prevalence, } \% \\
\text { (no. birds examined) }\end{array}$ & $\begin{array}{l}\text { No. loci } \\
\text { (no. birds examined) }\end{array}$ & $H^{\mathrm{a}}$ & $P 99^{\mathrm{a}}$ & $P 95^{\mathrm{a}}$ & Sources $^{\mathrm{b}}$ \\
\hline \multicolumn{7}{|l|}{ Alaudidae } \\
\hline $\begin{array}{l}\text { Eremophila alpestris } \\
\text { Alcidae }\end{array}$ & $13.0(23)$ & $35(17)$ & 0.102 & - & - & 1 \\
\hline \multicolumn{5}{|l|}{ Anatidae } & 0.119 & 2 \\
\hline $\begin{array}{l}\text { Anas americana } \\
\text { Anas platyrynchos } \\
\text { Anas rubripes } \\
\text { Branta canadensis } \\
\text { Chen caerulescens }\end{array}$ & $\begin{array}{l}20.1(279) \\
27.0(1901) \\
54.4(2658) \\
6.4(1148) \\
3.5(577)\end{array}$ & $\begin{array}{l}25(1247) \\
30(752) \\
29(131) \\
35(249) \\
41(550)\end{array}$ & $\begin{array}{l}0.082 \\
0.073 \\
0.053 \\
0.051 \\
0.029\end{array}$ & $\begin{array}{l}0.560 \\
0.218 \\
0.260 \\
0.322 \\
0.146\end{array}$ & $\begin{array}{l}0.280 \\
0.176 \\
0.183 \\
0.210 \\
0.146\end{array}$ & $\begin{array}{l}3,4 \\
5-7 \\
5 \\
8 \\
9\end{array}$ \\
\hline \multicolumn{7}{|l|}{ Ardeidae } \\
\hline & \multicolumn{2}{|c|}{ Charadriidae } & 0.007 & 0.107 & 0.036 & 10 \\
\hline \multicolumn{7}{|l|}{ Emberizidae } \\
\hline Agelaius phoeniceus & $14.9(1486)$ & $28(292)$ & 0.037 & 0.276 & 0.124 & 12 \\
\hline Ammodramus savannarum & $3.0(33)$ & $20(10)$ & 0.045 & 0.200 & 0.200 & 13 \\
\hline Dendroica caerulescens & $17.6(17)$ & $26(6)$ & 0.040 & - & - & 14 \\
\hline Dendroica castanea & $27.7(47)$ & $26(12)$ & 0.024 & - & - & 14 \\
\hline Dendroica coronata & $54.6(423)$ & $32(140)$ & 0.035 & 0.333 & 0.222 & 15,16 \\
\hline Dendroica discolor & $3.2(31)$ & $26(8)$ & 0.012 & - & - & 14 \\
\hline Dendroica fusca & $43.8(32)$ & $26(8)$ & 0.036 & - & - & 14 \\
\hline Dendroica magnolia & $44.2(147)$ & $26(12)$ & 0.004 & - & - & 14 \\
\hline Dendroica palmarum & $20.0(15)$ & $29(45)$ & 0.040 & 0.323 & 0.323 & 16 \\
\hline Dendroica pensylvanica & $49.4(83)$ & $26(10)$ & 0.014 & - & - & 14 \\
\hline Dendroica petechia & $52.0(296)$ & $26(2)$ & 0.068 & - & - & 14 \\
\hline Dendroica pinus & $23.0(135)$ & $26(2)$ & 0.050 & - & - & 14 \\
\hline Dendroica tigrina & $56.1(41)$ & $26(6)$ & 0.033 & - & - & 14 \\
\hline Dendroica virens & $27.0(63)$ & $26(2)$ & 0.024 & - & - & 14 \\
\hline Geothlypsis trichas & $25.5(196)$ & $26(32)$ & 0.037 & - & - & 14 \\
\hline Icteria virens & $80.0(10)$ & $26(5)$ & 0.020 & - & - & 14 \\
\hline Junco hyemalis & $28.3(360)$ & 34 (112) & 0.038 & 0.165 & 0.136 & $13,17,18$ \\
\hline Melospiza georgiana & $60.9(304)$ & $30(26)$ & 0.045 & 0.217 & 0.183 & 13,18 \\
\hline Melospiza lincolnii & $59.0(78)$ & $39(8)$ & 0.054 & 0.179 & 0.179 & 18 \\
\hline Melospiza melodia & $34.9(1518)$ & $39(14)$ & 0.042 & 0.179 & 0.154 & 18 \\
\hline Mniotilta varia & $35.0(123)$ & $26(6)$ & 0.026 & - & - & 14 \\
\hline Parula americana & $33.3(57)$ & $26(6)$ & 0.030 & - & - & 14 \\
\hline Passerculus sandwichensis & $30.6(173)$ & $20(10)$ & 0.049 & 0.250 & 0.250 & 13 \\
\hline Passerella iliaca & $76.7(477)$ & $39(57)$ & 0.036 & 0.308 & 0.128 & 18 \\
\hline Pipilo erythrophthalmus & $33.1(169)$ & $39(17)$ & 0.146 & - & - & 19 \\
\hline Pipilo fuscus & $34.6(78)$ & $21(32)$ & 0.033 & 0.110 & 0.110 & 13,20 \\
\hline Seiurus aurocapillus & $23.6(127)$ & $26(29)$ & 0.061 & - & - & 16 \\
\hline Seiurus noveboracensis & $70.0(423)$ & $29(31)$ & 0.088 & 0.452 & 0.419 & 16 \\
\hline Setophaga ruticilla & $29.0(283)$ & $26(16)$ & 0.031 & - & - & 14 \\
\hline Spizella passerina & $34.2(465)$ & $21(11)$ & 0.065 & 0.143 & 0.143 & 13 \\
\hline Spizella pusilla & $21.9(151)$ & $21(6)$ & 0.083 & 0.143 & 0.143 & 13 \\
\hline Vermivora celata & $18.8(32)$ & $26(12)$ & 0.040 & - & - & 14 \\
\hline Vermivora peregrina & $26.5(253)$ & $28(37)$ & 0.055 & 0.333 & 0.333 & 14,16 \\
\hline Zonotrichia albicollis & $55.0(1075)$ & $39(22)$ & 0.048 & 0.267 & 0.200 & 13,18 \\
\hline Zonotrichia atricapilla & $27.8(212)$ & $39(15)$ & 0.039 & 0.154 & 0.154 & 18 \\
\hline Zonotrichia leucophrys & $47.1(425)$ & $46(352)$ & 0.055 & 0.331 & 0.235 & $17,18,21-23$ \\
\hline Zonotrichia querula & $21.1(19)$ & $39(32)$ & 0.023 & 0.123 & 0.111 & 17,18 \\
\hline \multicolumn{7}{|l|}{ Fringillidae } \\
\hline Carduelis flammea & $66.7(21)$ & $33(5)$ & 0.021 & 0.034 & 0.034 & 24 \\
\hline Carduelis pinus & $40.5(37)$ & $33(6)$ & 0.035 & 0.138 & 0.138 & 24 \\
\hline Carduelis psaltria & $15.4(13)$ & $33(4)$ & 0.017 & 0.034 & 0.034 & 24 \\
\hline Carduelis tristis & $24.7(77)$ & $33(7)$ & 0.016 & 0.034 & 0.034 & 24 \\
\hline Carpodacus cassinii & $72.7(11)$ & $33(12)$ & 0.026 & 0.212 & 0.138 & 24 \\
\hline Carpodacus mexicanus & $14.8(714)$ & 33 (19) & 0.040 & 0.333 & 0.207 & 24 \\
\hline Carpodacus purpureus & $67.7(226)$ & $33(15)$ & 0.034 & 0.138 & 0.138 & 24 \\
\hline Coccothraustes vespertinus & $56.8(37)$ & $33(4)$ & 0.044 & 0.069 & 0.069 & 24 \\
\hline Loxia leucoptera & $53.8(13)$ & $33(3)$ & 0.103 & 0.206 & 0.206 & 24 \\
\hline Pinicola enucleator & $88.7(62)$ & $33(7)$ & 0.052 & 0.155 & 0.155 & 24 \\
\hline \multicolumn{7}{|l|}{ Laridae } \\
\hline Larus ridibundus & $4.5(22)$ & $29(15)$ & 0.041 & 0.207 & 0.172 & 25 \\
\hline Sterna hirundo & $0.0(587)$ & $34(82)$ & 0.044 & 0.199 & 0.147 & 26 \\
\hline \multicolumn{7}{|l|}{ Mimidae } \\
\hline Dumetella carolinensis & $20.0(235)$ & $24(32)$ & 0.026 & 0.213 & 0.128 & 27,28 \\
\hline Mimus polyglottos & $29.2(212)$ & $23(8)$ & 0.010 & 0.053 & 0.053 & 28 \\
\hline Toxostoma rufum & $45.4(401)$ & $23(7)$ & 0.048 & 0.130 & 0.130 & 28 \\
\hline
\end{tabular}


Table 1. (cont.)

\begin{tabular}{|c|c|c|c|c|c|c|}
\hline $\begin{array}{l}\text { Family } \\
\text { species }\end{array}$ & $\begin{array}{l}\text { Prevalence, } \% \\
\text { (no. birds examined) }\end{array}$ & $\begin{array}{l}\text { No. loci } \\
\text { (no. birds examined) }\end{array}$ & $H^{\mathrm{a}}$ & $P 99^{\mathrm{a}}$ & $P 95^{\mathrm{a}}$ & Sources $^{b}$ \\
\hline \multicolumn{7}{|l|}{ Muscicapidae } \\
\hline Catharus fuscescens & $41.8(91)$ & $27(5)$ & 0.056 & 0.185 & 0.185 & 27 \\
\hline Catharus guttatus & $40.9(88)$ & $27(13)$ & 0.047 & 0.259 & 0.148 & 27 \\
\hline Catharus minimus & $76.2(193)$ & $26(2)$ & 0.021 & 0.077 & 0.077 & 27 \\
\hline Catharus ustulatus & $58.7(446)$ & $27(22)$ & 0.048 & 0.300 & 0.148 & 14,27 \\
\hline Hylocichla mustelina & $32.1(28)$ & $27(5)$ & 0.104 & 0.148 & 0.148 & 27 \\
\hline Sialia sialis & $16.1(56)$ & $27(7)$ & 0.063 & 0.222 & 0.222 & 27 \\
\hline Turdus migratorius & $73.5(1323)$ & $26(5)$ & 0.042 & 0.077 & 0.077 & 27 \\
\hline \multicolumn{7}{|l|}{ Odontophoridae } \\
\hline Callipepla californica & $23.6(89)$ & $32(134)$ & 0.030 & 0.169 & 0.123 & 29,30 \\
\hline Callipepla gambelii & 89.7 (907) & $27(22)$ & 0.025 & 0.185 & 0.111 & 29 \\
\hline Callipepla squamata & $23.1(134)$ & $27(29)$ & 0.032 & 0.130 & 0.130 & 29 \\
\hline Colinus virginianus & $1.8(947)$ & $27(15)$ & 0.027 & 0.148 & 0.148 & 29 \\
\hline \multirow{2}{*}{\multicolumn{7}{|c|}{ Paridae }} \\
\hline & & & & & & \\
\hline Parus atricapillus & $54.4(228)$ & $35(20)$ & 0.046 & 0.229 & 0.114 & 31 \\
\hline Parus bicolor & $0.0(14)$ & $36(24)$ & 0.060 & 0.306 & 0.181 & 32 \\
\hline Parus carolinensis & $6.8(44)$ & $35(20)$ & 0.042 & 0.314 & 0.200 & 31 \\
\hline Parus gambeli & $35.7(14)$ & $33(15)$ & 0.020 & 0.152 & 0.121 & 31 \\
\hline \multicolumn{7}{|l|}{ Passeridae } \\
\hline Passer domesticus & $18.2(5202)$ & $33(581)$ & 0.100 & 0.478 & 0.296 & $33-35$ \\
\hline Passer montanus & $29.3(280)$ & $39(93)$ & 0.078 & 0.445 & 0.220 & 36 \\
\hline \multicolumn{7}{|l|}{ Phasianidae } \\
\hline Alectoris chukar & $0.0(24)$ & $33(20)$ & 0.085 & 0.394 & 0.333 & 37 \\
\hline Lagopus lagopus & $28.4(222)$ & $23(269)$ & 0.082 & 0.260 & 0.260 & 38 \\
\hline Phasianus colchicus & $0.0(441)$ & $27(98)$ & 0.056 & 0.312 & 0.226 & 29,39 \\
\hline Tympanuchus phasianellus & $82.8(134)$ & $30(22)$ & 0.046 & 0.200 & 0.133 & 40 \\
\hline \multicolumn{7}{|l|}{ Picidae } \\
\hline Colaptes auratus & $52.0(177)$ & $31(356)$ & 0.075 & 0.299 & 0.259 & 41,42 \\
\hline Sphyrapicus varius & $33.3(39)$ & $39(7)$ & 0.022 & 0.128 & 0.103 & 43 \\
\hline \multicolumn{7}{|l|}{ Regulidae } \\
\hline Regulus calendula & $7.8(77)$ & $23(10)$ & 0.048 & 0.174 & 0.174 & 27 \\
\hline \multicolumn{7}{|l|}{ Scolopacidae } \\
\hline Calidris alpina & $0.0(18)$ & $29(25)$ & 0.009 & - & 0.138 & 11 \\
\hline Calidris fuscicolis & $0.0(13)$ & $40(56)$ & 0.023 & - & 0.205 & 11 \\
\hline Calidris maritima & $0.0(13)$ & $40(35)$ & 0.006 & - & 0.069 & 11 \\
\hline Calidris minutilla & $0.0(43)$ & $39(25)$ & 0.030 & - & 0.205 & 11 \\
\hline Calidris pusilla & $0.0(67)$ & $40(25)$ & 0.038 & - & 0.175 & 11 \\
\hline Limnodromus griseus & $30.0(10)$ & $39(28)$ & 0.018 & 0.054 & 0.062 & 11,44 \\
\hline \multicolumn{7}{|l|}{ Sturnidae } \\
\hline Sturnus vulgaris & $2.8(604)$ & $24(298)$ & 0.031 & - & 0.210 & 45 \\
\hline \multicolumn{7}{|l|}{ Tyrannidae } \\
\hline Contopus sordidulus & $35.7(14)$ & $38(5)$ & 0.067 & - & 0.231 & 46 \\
\hline Contopus virens & $37.0(27)$ & $38(7)$ & 0.084 & - & 0.308 & 46 \\
\hline Empidonax difficilis & $60.0(10)$ & $40(388)$ & 0.053 & 0.261 & 0.158 & 46,47 \\
\hline Empidonax flaviventris & $5.6(36)$ & 38 (19) & 0.050 & - & 0.282 & 46 \\
\hline Empidonax minimus & 7.7 (13) & $38(18)$ & 0.050 & - & 0.154 & 46 \\
\hline Empidonax traillii & $12.0(83)$ & $37(49)$ & 0.072 & 0.321 & 0.268 & 46,48 \\
\hline \multicolumn{7}{|l|}{ Vireonidae } \\
\hline Vireo flavifrons & $30.0(10)$ & $23(4)$ & 0.043 & 0.174 & 0.174 & 28 \\
\hline Vireo griseus & $40.6(32)$ & $23(10)$ & 0.036 & 0.087 & 0.081 & 28,49 \\
\hline Vireo olivaceus & $59.4(187)$ & 31 (109) & 0.057 & 0.411 & 0.233 & $14,19,28,49$ \\
\hline Vireo solitarius & $40.7(27)$ & $23(21)$ & 0.053 & 0.211 & 0.154 & 28,49 \\
\hline
\end{tabular}

${ }^{a} H$, heterozygosity; $P 99$, polymorphism with criterion that the frequency of the most common allele is $\leq 0.99$; $P 95$, polymorphism with criterion that the frequency of the most common allele is $\leq 0.95$.

${ }^{\mathrm{b}}$ Sources of the genetic data: 1, Evans (1987); 2, Moen (1991); 3 , Rhodes, Smith \& Chesser (1993); 4, Rhodes \& Smith (1993); 5, Ankney et al. (1986); 6, Rhodes, Smith \& Chesser (1995); 7, Rhodes, Smith \& Smith (1996); 8, van Wagner \& Baker (1986); 9, Cooke, Parkin \& Rockwell (1988); 10, Guttman, Grau \& Karlin (1980); 11, Baker \& Strauch (1986); 12, Gavin, Howard \& May (1991); 13, Avise, Patton \& Aquadro (1980c); 14, Avise, Patton \& Aquadro (1980a); 15, Barrowclough (1980); 16, Barrowclough \& Corbin (1978); 17, Zink \& Watt (1987); 18, Zink (1982); 19, Barrowclough et al. (1985); 20, Zink (1988); 21, Corbin \& Wilkie (1988); 22, Baker (1976); 23, Corbin (1981); 24, Marten \& Johnson (1986); 25, Randi \& Spina (1987); 26, Burson (1990); 27, Avise, Patton \& Aquadro (1980b); 28, Avise, Aquadro \& Patton (1982); 29, Gutierrez, Zink \& Yang (1983); 30, Zink, Lott \& Anderson (1987); 31, Braun \& Robbins (1986); 32, Braun, Kitto \& Braun (1984); 33, Stangel, Rodgers \& Bryan (1990); 34, Bates \& Zink (1992); 35,

Parkin \& Cole (1984); 36, St Louis \& Barlow (1988); 37, Randi et al. (1992); 38, Gyllensten, Reuterall \& Ryman (1979); 39, Scribner, Dowell \& Warren (1989); 40, Ellsworth et al. (1994); 41, Grudzien et al. (1987); 42, Grudzien \& Moore (1986); 43, Johnson \& Zink (1983); 44, Avise \& Zink (1988); 45, Ross (1983); 46, Zink \& Johnson (1984); 47, Johnson \& Marten (1988); 48, Seutin \& Simon (1988); 49, Johnson, Zink \& Marten (1988). 


\section{DISCUSSION}

If the short generation times and high evolutionary rates of parasites select for rare alleles and maintain variation among hosts, then host species exposed to higher prevalence of parasites should also display substantial genetic variation. Here we examined whether parasitism is associated with genome-wide diversity across host species. We failed to find any correlation between prevalence of blood parasites and levels of genetic variation among a large number of bird species. The same result was obtained both after removing the confounding effects of avian phylogeny and sampling effort, and when we used raw species values as independent observations. There are three possible explanations for this outcome: poor quality data, parasite prevalence being an inadequate measure of selection pressure, and electrophoretic loci being unaffected by parasite-mediated selection.

A common explanation for a failure to find a significant relationship where one is expected is that the data are of poor quality and/or contain too much noise. We tried to eliminate species for which the accuracy of the data was questionable. However, neither relaxing the criteria for inclusion of species in the data set, nor using tougher criteria, had any effect on the outcome of the analysis. Our survey found that levels of genetic variation differ slightly between populations of the same bird species. Examining different loci or even the same loci under different laboratory conditions can produce different estimates of genetic variation. It is noteworthy, however, that similar data have been used previously to uncover correlations between life-history characters and levels of genetic variation in fish and birds (Mitton \& Lewis, 1989; Petrie et al., 1998). Data on haematozoan prevalence also often show spatial and temporal variation within host species, and this variability could perhaps mask existing relationships (Yezerinac \& Weatherhead, 1995; John, 1997). Nevertheless, the same parasite prevalence data used here have been shown in other studies to reveal significant patterns between parasitism and bird ecology even when fewer bird species were included (Read, 1991; Ricklefs, 1992; John, 1995; Sorci \& Møller, 1997). The power of our tests to detect statistically significant non-zero correlations was also high. For instance, if the true correlation was 0.4 (explaining just $16 \%$ of the observed data scatter), even our smallest data set ( $n=52$ contrasts) had a $>84 \%$ chance of giving a statistically significant $(P<0.05)$ result. If the true correlation was 0.5 , our power rises to c. $97 \%$. Hence, we do not think that the quality or noisiness of either data set has masked any real relationship.

A second reason for the apparent absence of relationships between parasitism and genetic variation may be that variation within particular parasite species in infective ability, and hence selection pressure, is of little consequence to host resistance. There is consequently no evolutionary arms race and so overall parasite prevalence need not correlate with genetic variation.
Given the results of within-species comparisons (e.g. Lively et al., 1990; Liersch \& Schmid-Hempel, 1998; Paterson et al., 1998), however, we think this explanation is unlikely. Nevertheless, richness of parasite species might still correlate positively with genetic variation since it would reflect a more varied source of selection pressure. Data on richness of parasite species in birds, unfortunately, are not as readily available.

Finally, the data on heterozygosity and polymorphism have been obtained for loci that are not known to be directly involved in resistance against parasites. The problem with this explanation is that it leaves unanswered the very question we set out to investigate: why are such loci variable? Moreover, this explanation implies that frequency-dependent selection by parasites only affects some fraction of loci. If parasites are responsible for the evolution of such a fundamental phenomenon as sex, one might have thought their effect would be more pervasive.

Although not significant, all correlation coefficients between parasite prevalence and genetic variation are negative (Fig. 1), suggesting a weak tendency for avian taxa with high parasite prevalence to be less variable than their sister taxa with lower prevalence. If another, unidentified factor is maintaining genetic variation in birds (e.g. frequency-dependent selection mediated by viral diseases), we might expect that the more variable species are more likely than less variable species to possess the rare alleles conferring resistance against widespread parasites. This idea, only very weakly supported by our analysis, would relegate parasites from agents promoting genetic variation to incidental victims of the variation maintained by other processes.

\section{Acknowledgements}

We thank F. Thomas and G. P. Wallis for commenting on an earlier draft of the paper. L. J. Marshall was supported by a University of Otago Summer Research Bursary.

\section{REFERENCES}

American Ornithologists' Union (1983). Checklist of North American birds. 6th edn. Lawrence, KS: Allen Press.

Ankney, C. D., Dennis, D. G., Wishard, L. N. \& Steeb, J. E. (1986). Low genic variation between black ducks and mallards. Auk 103: 701-709.

Apanius, V., Penn, D., Slev, P. R., Ruff, L. R. \& Potts, W. K. (1997). The nature of selection on the major histocompatibility complex. Crit. Rev. Immunol. 17: 179-224.

Atkinson, C. T. \& van Riper, C. (1991). Pathogenicity and epizootiology of avian haematozoa: Plasmodium, Leucocytozoon, and Haemoproteus. In Bird-parasite interactions: ecology, evolution and behaviour: 19-48. Loye, J. E. \& Zuk, M. (Eds). Oxford: Oxford University Press.

Avise, J. C., Aquadro, C. F. \& Patton, J. C. (1982). Evolutionary genetics of birds. V. Genetic distances within Mimidae (mimic thrushes) and Vireonidae (vireos). Biochem. Genet. 20: 95-104. 
Avise, J. C., Patton, J. C. \& Aquadro, C. F. (1980a). Comparative molecular evolution in New World warblers and rodents. J. Hered. 71: 303-310.

Avise, J. C., Patton, J. C. \& Aquadro, C. F. (1980b). Evolutionary genetics of birds. I. Relationships among North American thrushes and allies. Auk 97: 135-147.

Avise, J. C., Patton, J. C. \& Aquadro, C. F. (1980c). Evolutionary genetics of birds. II. Conservative protein evolution in North American sparrows and relatives. Syst. Zool. 29: 323-334.

Avise, J. C. \& Zink, R. M. (1988). Molecular genetic divergence between avian sibling species: king and clapper rails, long-billed and short-billed dowitchers, boat-tailed and great-tailed grackles, and tufted and black-crested titmice. Auk 105: 516-528.

Baker, A. J. \& Strauch, J. G. Jr. (1986). Genetic variation and differentiation in shorebirds. In Acta XIX Congressus Internationalis Ornithologici 2: 1639-1645. Ouellet, H. (Ed.). Ottawa: National Museum of Natural Sciences.

Baker, M. C. (1976). Genetic structure of two populations of white-crowned sparrows with different song dialects. Condor 76: $351-356$.

Barrowclough, G. F. (1980). Genetic and phenotypic differentiation in a wood warbler (genus Dendroica) hybrid zone. Auk 97: 655-668.

Barrowclough, G. F. \& Corbin, K. W. (1978). Genetic variation and differentiation in the Parulidae. Auk 95: 691-702.

Barrowclough, G. F., Johnson, N. K. \& Zink, R. M. (1985). On the nature of genic variation in birds. In Current ornithology 2 : 135-154. Johnston, R. F. (Ed.). New York: Plenum Press.

Bates, J. M. \& Zink, R. M. (1992). Seasonal variation in gene frequencies in the house sparrow (Passer domesticus). Auk 109: 658-662.

Braun, D., Kitto, G. B. \& Braun, M. J. (1984). Molecular population genetics of tufted and black-crested forms of Parus bicolor. Auk 101: 170-173.

Braun, M. J. \& Robbins, M. B. (1986). Extensive protein similarity of the hybridizing chickadees Parus atricapillus and P. carolinensis. Auk 103: 667-675.

Burson, S. L. I. (1990). Population genetics and gene flow of the common tern. Condor 92: 182-192.

Chaboudez, P. \& Burdon, J. J. (1995). Frequency-dependent selection in a wild plant-pathogen system. Oecologia (Berl.) 102: 490-493.

Clarke, B. C. \& Partridge, L. (1988). Frequency-dependent selection. London: Royal Society.

Clay, K. \& Kover, P. X. (1996). The Red Queen hypothesis and plant/pathogen interactions. Annu. Rev. Phytopathol. 34: 29-50.

Cooke, F., Parkin, D. T. \& Rockwell, R. F. (1988). Evidence of former allopatry of the two color phases of lesser snow geese (Chen caerulescens caerulescens). Auk 105: 467-479.

Corbin, K. W. (1981). Genic heterozygosity in the white-crowned sparrow: a potential index to boundaries between subspecies. Auk 98: 669-680.

Corbin, K. W. \& Wilkie, P. J. (1988). Genetic similarities between subspecies of the white-crowned sparrow. Condor 90: 637-647.

Dunning, J. B. Jr. (1993). CRC handbook of avian body masses. Boca Raton, FL: CRC Press.

Dybdahl, M. F. \& Lively, C. M. (1995). Diverse, endemic and polyphyletic clones in mixed populations of a freshwater snail (Potamopyrgus antipodarum). J. Evol. Biol. 8: 385-398.

Ellsworth, D. L., Honeycutt, R. L., Silvy, N. J., Rittenhouse, K. D. \& Smith, M. H. (1994). Mitochondrial-DNA and nuclear-gene differentiation in North American prairie grouse (genus Tympanuchus). Auk 111: 661-671.

Evans, P. G. H. (1987). Electrophoretic variability of gene products. In Avian genetics: a population and ecological approach: 105-162. Cooke, F. \& Buckley, P. A. (Eds). London: Academic Press.

Felsenstein, J. (1985). Phylogenies and the comparative method. Am. Nat. 125: 1-15.
Garland, T., Harvey, P. H. \& Ives, A. R. (1992). Procedures for the analysis of comparative data using phylogenetically independent contrasts. Syst. Biol. 41: 18-32.

Gavin, T. A., Howard, R. A. \& May, B. (1991). Allozyme variation among breeding populations of red-winged blackbirds: the Californian conundrum. Auk 108: 602-611.

Gorman, G. C. \& Renzi, J. (1979). Genetic distance and heterozygosity estimates in electrophoretic studies: effects of sample size. Copeia 1979: 242-249.

Gregory, R. D. \& Blackburn, T. M. (1991). Parasite prevalence and host sample size. Parasitol. Today 7: 316-318.

Greiner, E. C., Bennett, G. F., White, E. M. \& Coombs, R. F. (1975). Distribution of the avian hematozoa of North America. Can. J. Zool. 53: 1762-1787.

Grudzien, T. A. \& Moore, W. S. (1986). Genetic differentiation between the yellow-shafted and red-shafted subspecies of the northern flicker. Biochem. Syst. Ecol. 14: 451-453.

Grudzien, T. A., Moore, W. S., Cook, J. R. \& Tagle, D. (1987). Genic population structure and gene flow in the northern flicker (Colaptes auratus) hybrid zone. Auk 104: 654-664.

Gutierrez, R. J., Zink, R. M. \& Yang, S. Y. (1983). Genic variation, systematic, and biogeographic relationships of some galliform birds. Auk 100: 33-47.

Guttman, S. I., Grau, G. A. \& Karlin, A. A. (1980). Genetic variation in Lake Erie great blue herons (Ardea herodias). Comp. Biochem. Physiol. B Comp. Biochem. 66: 167-169.

Gyllensten, U., Reuterall, C. \& Ryman, N. (1979). Genetic variability in Scandinavian populations of willow grouse (Lagopus lagopus L.) and rock ptarmigan (Lagopus mutus L.). Hereditas 91: 301.

Hamilton, W. D. (1980). Sex versus non-sex versus parasite. Oikos 35: $282-290$.

Hamilton, W. D. (1982). Pathogens as causes of genetic diversity in their host populations. In Population biology of infectious diseases: 269-296. Anderson, R. M. \& May, R. M. (Eds). New York: Springer.

Hamilton, W. D., Axelrod, R. \& Tanese, R. (1990). Sexual reproduction as an adaptation to resist parasites (a review). Proc. Natl Acad. Sci. USA 87: 3566-3573.

Hamilton, W. D. \& Zuk, M. (1982). Heritable true fitness and bright birds: a role for parasites? Science 218: 384-387.

John, J. L. (1995). Haematozoan parasites, mating systems and colourful plumages in songbirds. Oikos 72: $395-401$.

John, J. L. (1997). The Hamilton-Zuk theory and initial test: an examination of some parasitological criticisms. Int. J. Parasitol. 27: $1269-1288$.

Johnson, N. K. \& Marten, J. A. (1988). Evolutionary genetics of flycatchers. II. Differentiation in the Empidonax difficilis complex. Auk 105: 177-191.

Johnson, N. K. \& Zink, R. M. (1983). Speciation in sapsuckers (Sphyrapicus): I. Genetic differentiation. Auk 100: 871-884.

Johnson, N. K., Zink, R. M. \& Marten, J.A. (1988). Genetic evidence for relationships in the avian family Vireonidae. Condor 90: 428-445.

Kimura, M. (1983). The neutral theory of molecular evolution. Cambridge: Cambridge University Press.

Kreitman, M. \& Akashi, H. (1995). Molecular evidence for natural selection. Annu. Rev. Ecol. Syst. 26: 403-422.

Lewontin, R. C. (1974). The genetic basis of evolutionary change. New York: Columbia University Press.

Liersch, S. \& Schmid-Hempel, P. (1998). Genetic variation within social insect colonies reduces parasite load. Proc. R. Soc. London B Biol. Sci. 265: 221-225.

Lively, C. M. (1987). Evidence from a New Zealand snail for the maintenance of sex by parasitism. Nature (Lond.) 328: 519-521.

Lively, C. M., Craddock, C. \& Vrijenhoek, R. C. (1990). Red Queen hypothesis supported by parasitism in sexual and clonal fish. Nature (Lond.) 344: 864-866. 
Mani, G. S. (1983). Evolutionary dynamics of genetic diversity. Berlin: Springer Verlag.

Marten, J. A. \& Johnson, N. K. (1986). Genetic relationships of North American cardueline finches. Condor 88: 409-420.

Martin, T. E. \& Clobert, J. (1996). Nest predation and avian lifehistory evolution in Europe versus North America: a possible role of humans? Am. Nat. 147: 1028-1046.

Maynard Smith, J. (1989). Evolutionary genetics. Oxford: Oxford University Press.

Mitton, J. B. \& Lewis, W. M. (1989). Relationships between genetic variability and life-history features of bony fishes. Evolution 43: 1712-1723.

Moen, S. M. (1991). Morphologic and genetic variation among breeding colonies of the Atlantic puffin (Fratercula arctica). Auk 108: 755-763.

Nei, M. (1978). Estimation of average heterozygosity and genetic distance from a small number of individuals. Genetics $\mathbf{8 9}$ $583-590$.

Nei, M. (1987). Molecular evolutionary genetics. New York: Columbia University Press.

Nei, M. \& Graur, D. (1984). Extent of protein polymorphism and the neutral mutation theory. Evol. Biol. 17: 73-118.

Nei, M. \& Roychoudhury, A. K. (1974). Sampling variance of heterozygosity and genetic distance. Genetics 76: 379-390.

Nevo, E. (1978). Genetic variation in natural populations: patterns and theory. Theor. Pop. Biol. 13: 121-177.

Parkin, D. T. \& Cole, S. R. (1984). Genetic variation in the house sparrow, Passer domesticus, in the East Midlands of England. Biol. J. Linn. Soc. 23: 287-301.

Paterson, S., Wilson, K. \& Pemberton, J. M. (1998). Major histocompatibility complex variation associated with juvenile survival and parasite resistance in a large unmanaged ungulate population (Ovis aries L.). Proc. Natl Acad. Sci. USA 95: $3714-3719$.

Peirce, M. A. (1981). Distribution and host-parasite check-list of the haematozoa of birds in Western Europe. J. Nat. Hist. 15: 419-458.

Petrie, M., Doums, C. \& Møller, A. P. (1998). The degree of extra-pair paternity increases with genetic variability. Proc. Natl Acad. Sci. USA 95: 9390-9395.

Purvis, A. \& Rambaut, A. (1994). Comparative Analysis by Independent Contrasts (C.A.I.C.), version 2.0. Oxford: Oxford University.

Randi, E., Meriggi, A., Lorenzini, R., Fusco, G. \& Alkon, P. U. (1992). Biochemical analysis of relationships of Mediterranean Alectoris partridges. Auk 109: 358-367.

Randi, E. \& Spina, F. (1987). An electrophoretic approach to the systematics of Italian gulls and terns (Aves, Laridae and Sternidae). Monit. Zool. Ital. 21: 317-344.

Read, A. F. (1991). Passerine polygyny: a role for parasites? Am. Nat. 138: $434-459$.

Rhodes, O. E. J. \& Smith, L. M. (1993). Relationships between genetic variation and carcass components in wintering American widgeon. Auk 110: 354-360.

Rhodes, O. E. J., Smith, L. M. \& Chesser, R. K. (1993). Temporal components of genetic variation in migrating and wintering American widgeon. Can. J. Zool. 71: 2229-2235.
Rhodes, O. E. J., Smith, L. M. \& Chesser, R. K. (1995). Apportionment of genetic variance in migrating and wintering mallards. Can. J. Zool. 73: 1182-1185.

Rhodes, O. E. J., Smith, L. M. \& Smith, M. H. (1996). Relationship between genetic variation and body size in wintering mallards. Auk 113: 339-345.

Ricklefs, R. E. (1992). Embryonic development period and the prevalence of avian blood parasites. Proc. Natl Acad. Sci. USA 89: 4722-4725.

Ronsheim, M. L. (1996). Evidence against a frequency-dependent advantage for sexual reproduction in Allium vineale. Am. Nat. 147: 718-734.

Ross, H. A. (1983). Genetic differentiation of starling (Sturnus vulgaris: Aves) populations in New Zealand and Great Britain. J. Zool. (Lond.) 201: 351-362.

Scribner, K. T., Dowell, J. H. \& Warren, R. J. (1989). Spatial genetic variability among introduced populations of the ringnecked pheasant. Southwest. Nat. 34: 27-34.

Seutin, G. \& Simon, J.-P. (1988). Genetic variation in sympatric willow flycatchers (Empidonax trailii) and alder flycatchers (E. alnorum). Auk 105: 235-243.

Sibley, C. G. \& Ahlquist, J. E. (1991). Phylogeny and classification of birds: a study in molecular evolution. New Haven, CT: Yale University Press.

Sorci, G. \& Møller, A. P. (1997). Comparative evidence for a positive correlation between haematozoan prevalence and mortality in waterfowl. J. Evol. Biol. 10: 731-741.

Spencer, H. G. \& Marks, R. W. (1993). The evolutionary construction of molecular polymorphisms. N. Z. J. Bot. 31: 249-256.

Stangel, P. W., Rodgers, J. A. \& Bryan, A. L. (1990). Genetic variation and population structure of the Florida wood stork. Auk 107: 614-619.

St Louis, V. L. \& Barlow, J. C. (1988). Genetic differentiation among ancestral and introduced populations of the Eurasian tree sparrow (Passer montanus). Evolution 42: 266-276.

Van Wagner, C. E. \& Baker, A. J. (1986). Genetic differentiation in populations of Canada geese (Branta canadensis). Can. J. Zool. 64: 940-947.

Westneat, D. F. \& Sherman, P. W. (1997). Density and extra-pair fertilizations in birds: a comparative analysis. Behav. Ecol. Sociobiol. 41: 205-215.

Yezerinac, S. M. \& Weatherhead, P. J. (1995). Plumage coloration, differential attraction of vectors and haematozoa infections in birds. J. Anim. Ecol. 64: 528-537.

Zink, R. M. (1982). Patterns of genic and morphologic variation among sparrows in the genera Zonotrichia, Melospiza, Junco, and Passerella. Auk 99: 632-649.

Zink, R. M. (1988). Evolution of brown towhees: allozymes, morphometrics and species limits. Condor 90: 72-82.

Zink, R. M. \& Johnson, N. K. (1984). Evolutionary genetics of flycatchers. I. Sibling species in the genera Empidonax and Contopus. Syst. Zool. 33: 205-216.

Zink, R. M., Lott, D. F. \& Anderson, D. W. (1987). Genetic variation, population structure, and evolution of Californian quail. Condor 89: 395-405.

Zink, R. M. \& Watt, D. J. 1987. Allozymic correlates of dominance rank in sparrows. Auk 104: 1-10. 